\title{
Laminated Veneer Lumber (LVL) Sengon: An Innovative Sustainable Building Material in Indonesia
}

\author{
Ali Awaludin ${ }^{*}$, Shahiron Shahidan ${ }^{2}$, Achmad Basuki $^{1}$, Sharifah Salwa Mohd \\ Zuki $^{2}$, Fadzli Mohamed Nazri ${ }^{3}$
}

${ }^{1}$ Department of Civil and Environmental Engineering, Faculty of Engineering, Universitas Gadjah Mada, Yogyakarta Grafika Street \#2, UGM campus, Sleman, Yogyakarta 55281.

${ }^{2}$ Jamilus Research Center, Faculty of Civil and Environmental Engineering, Universiti Tun Hussein Onn Malaysia, Johor Bahru Batu Pahat

${ }^{3}$ School of Civil Engineering, USM, Engineering Campus, 14300 Nibong Tebal, Seberang Perai Selatan, P. Pinang, MALAYSIA

DOI: https://doi.org/10.30880/ijie.2018.10.01.003

Received 12 October 2017; accepted 28 December 2017; available online 9 January 2018

\begin{abstract}
Laminated Veneer Lumber (LVL) is recently available in Indonesian markets. The veneers are majority from Sengon wood (Paraserianthes falcataria), which is a fast-growing timber species native to Indonesia. Their use in practice is limited to non-structural components since Sengon wood species has low engineering properties and less resistance to termite attacks. The LVL production introduced few years ago has significantly improved both mechanical properties and durability as well as has expanded its utilization into various structural components. This remarkable improvement has made LVL Sengon wood as an innovative sustainable building materials in Indonesia. This paper summarized a series of authors' work conducted since couple years ago to initiate the utilization of LVL Sengon in structural components such as shear walls and floor systems as parts of a project to develop its design standard. In addition, creep behavior of this LVL is also highlihgted here as this phenomenon is essential for designers and engineers to anticipate their designs within their service life. In particular, the test results showed that addition of diagonal members increased both racking resistance and equivalent viscous damping ratio of the developed LVL shear walls. And the LVL floor model which is composed of built-up box joists and plywood sheathing remained liniear-elastic under bearing load up to $18.75 \mathrm{kN} / 2$.
\end{abstract}

Keywords:

\section{Introduction}

Wood has served many decades to provide human with various things from non-structural elements such as papers and music instruments and to structural components such as houses, bridges, ships, electric poles, etc. It is because wood has comprehensive engineering properties, has high strength-to-weight ratio, is easy to work with, is a renewable material, and the most important aspect is green or environmentally friendly material. A quick comparison in term of environmental impact measured through amount of Carbon emission during production of $1 \mathrm{~m}^{3}$ between wood and other construction materials such as concrete, steel, and aluminum, is presented in Table 1 [1]. This fact is strongtly supported by the recent life cycle analysis under project of Athena Sustainable Material Incentive indicates that timber production has the lowest total energy use, green house gasses emission, air and water pollution compared to steel and concrete production [2].
Table 1 Amount of carbon released during production [1]

\begin{tabular}{lccc}
\hline Material & $\begin{array}{c}\text { Carbon } \\
\text { released } \\
(\mathrm{kg} / \mathrm{t})\end{array}$ & $\begin{array}{c}\text { Carbon } \\
\text { released } \\
\left(\mathrm{kg} / \mathrm{m}^{3}\right)\end{array}$ & $\begin{array}{c}\text { Carbon } \\
\text { Stored } \\
\left(\mathrm{kg} / \mathrm{m}^{3}\right)\end{array}$ \\
\hline Timber & 30 & 15 & 250 \\
Concrete & 50 & 120 & 0 \\
Steel & 700 & 5320 & 0 \\
Aluminum & 8700 & 22000 & 0 \\
\hline
\end{tabular}

The above mentioned crucial role of wood, however, is now continuously replaced by other construction materials as significant amount of deforestation has been observed to date. The Indonesian ministry of Environment and Forest reported that about $50 \%$ of Indonesian forest has gone from the year 1955 till 2016 with an average deforestation rate of 0.68 million ha per year [3]. Owing to know woods as a versatile material with various function as aformentioned and their ability to off-set Carbon gas, one of the most important 
component of Green House Gasses (GHG), what our life will be without woods. In year 2000, very few industries in Indonesia started to produce laminated veneer lumber (LVL) as main construction material of one-storey house as shown in Figure 1 for low-income people. LVL is one type of structural composite lumber that is manufactured by laminating veneers of 3.2 to $2.5 \mathrm{~mm}$ thick with all plies parallel to the length. The veneers used are mainly obtained from Sengon Wood (Paraserianthes falcataria), but sometimes in combination with veneers from Rubber wood (Hevea brasiliensis). They are hot-pressed with melamine urea-formaldehyde under 0.6-0.7 MPa pressure and $105-110^{\circ} \mathrm{C}$ to form LVL [4]. A study of the engineering properties of LVL Sengon summarized in Table 2 indicates that LVL technology has improved these properties significantly. Sengon is a fast-growing tree generally harvested in cuting age 5-7 years, while it can grow up to $40 \mathrm{~m}$ tall and up to $100 \mathrm{~cm}$ or sometimes more in diameter [5]. The authors believe that this LVL Sengon becomes one of new emerging and innovative construction materials nowadays in Indonesia.

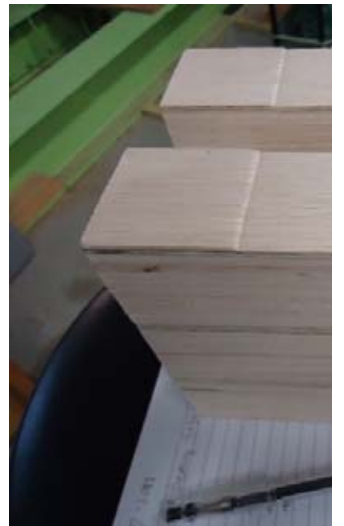

(a)

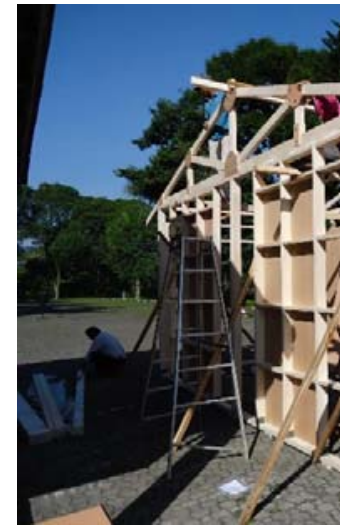

(b)
Fig. 1: LVL Paraserianthes falcaria: (a) example LVL product; (b) one-storey house made from LVL Sengon

Table 2 Improved engineering properties of Sengon wood through LVL technology

\begin{tabular}{lccc}
\hline \multicolumn{1}{c}{$\begin{array}{c}\text { Engineering } \\
\text { Properties }\end{array}$} & $\begin{array}{c}\text { Segon } \\
\text { solid }\end{array}$ & $\begin{array}{c}\text { LVL } \\
\text { Sengon }\end{array}$ & $\begin{array}{c}\text { LVL } \\
\text { Sengon- } \\
\text { Rubber } \\
\text { wood }\end{array}$ \\
\hline Density & 0.26 & 0.41 & 0.55 \\
MoE $(\mathrm{MPa})$ & 5530 & 7350 & 7511 \\
MoR $(\mathrm{MPa})$ & 26.61 & 38.78 & 51.40 \\
Tension//(MPa) & 20.00 & 46.69 & 40.80 \\
Tension $\perp(\mathrm{MPa})$ & 13.29 & 22.82 & 32.61 \\
Compression $/ /(\mathrm{MPa})$ & 2.09 & 4.03 & 5.40 \\
Compression $\perp(\mathrm{MPa})$ & 3.52 & 5.40 & - \\
Shear $(\mathrm{MPa})$ & 0.60 & - & 1.80 \\
\hline
\end{tabular}

Current huge housing backlog in Indonesia is estimated around 13.5 million in term of ownership and 7.6 million in term of access in addition to the 3.4 million of very poor houses [6] has forced the government to massively construct multi-storey dwellings rather than one-storey houses. Thus it is a great opportunity for LVL Sengon to further be utilized in multi-storey housings. In this regards, this paper is aimed to elaborate two important issues that LVL housing has to dealt with: floor system and lateral force resisting system during an event of earthquake. These are elaborated in the following sections of this paper.

\section{LVL Shear Walls}

Shear walls in wooden construction is obtaned by attaching sheathing materials such as plywood or oriented strand board to timber frames where they are connecting by nails or screws at the perimeter of the sheathing materials as shown in Figure 2. Applying energy work principle, Tuomi et al. [7] developed an equation to predict the racking resistance of a wooden shear wall. It is influenced by the shear wall geometry including number of metal connectors at the sheathing perimeter, shear modulus of the sheathing material, and load carrying capacity of sheathing-to-frame connection. Openings of the wooden shear walls such as for window use or other purposes significantly reduce their racking resistances $[8$, 9].
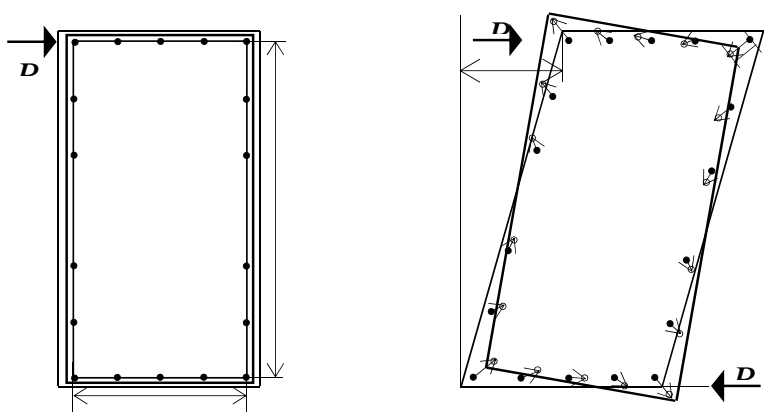

Fig. 2 Wooden shear wall under lateral force: Undeformed and deformed sahpes [7]

In 2010 Hadi et al. [10] conducted destructive test on two mutually parallel shear walls having dimension of $2700 \mathrm{~mm}$ in height and $6000 \mathrm{~mm}$ in length. These walls consisted of LVL Sengon-Rubber composite frames and Cement Fiber Boards (CFBs) connected at perimeter of the board using smooth shank nails with a diameter of 2.7 $\mathrm{mm}$ and length of $50 \mathrm{~mm}$ (CN50). Based on their test results they concluded that a non-engineered earthquake resistant type 36 house, the standard house with floor plan of $6 \mathrm{~m}$ by $6 \mathrm{~m}$ for low-income people, needs two shear walls of $2.7 \mathrm{~m}$ height by $6 \mathrm{~m}$ length without opening to resist the predicted seismic force at the zone with highest risk of earthquake in Indonesia.

Awaludin [4] have tested sheathing-to-frame connections where both frame member and sheathing material were LVL Sengon and metal fasteners used was 
$\mathrm{CN} 50$. Figure 3 shows photos of the test and typical failures of connection under cyclic loads. Adopting similar test method, this study tested the same sheathingto-frame connections and replacing the CN50 by screws (diameter $4 \mathrm{~mm}$; length $50 \mathrm{~mm}$ ). Six screwed connections were prepared in monotonic test, while only three screwed connections were prepared in the reversed-cyclic test. In the reversed-cyclic test, the loading protocol used is displacement-controlled consisted of five displacement targets: $0.25 \Delta_{\mathrm{y}}, 0.5 \Delta_{\mathrm{y}}, 0.75 \Delta_{\mathrm{y}}, 1.0 \Delta_{\mathrm{y}}$, and $1.25 \Delta_{\mathrm{y}}$, where $\Delta_{\mathrm{y}}$ is the connection displacement corresponds to 0.8 times of the maximum load of the monotonic test specimens.

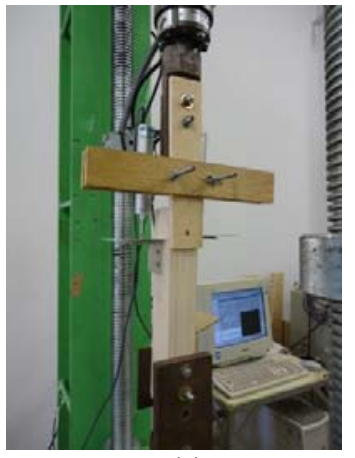

(a)

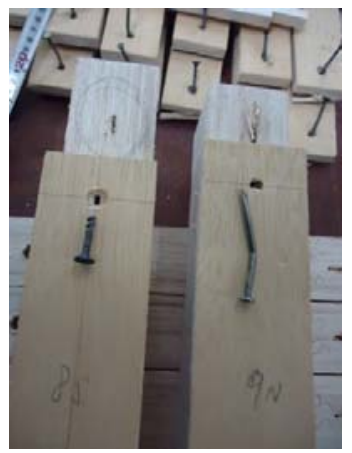

(b)
Fig. 3: Test of LVL Sengon sheathing-to-frame connections: (a) a connection during loaded; (b) typical failure connection under cyclic loads

Results of the monotonic test shown in Figure 4 indicated that sheathing-to-frame connections using screws gave higher lateral load at initial slip occurence, load carrying capacity, and smooth softening after reaching the maximum load than those of the connections using nails. The average load carrying capacity of the sheathing-to-frame connections developed here was found to be about $60 \%$ and $40 \%$ of the one developed by Hadi [10] for the connections with screws and nails, respectively. Thus it is preferable to use screws instead of CN50 for the application of LVL Segon walls in earthquake-resistant houses as the required length of the shear wall would still be feasible to manage. The results of cyclic test of the nail and screwed connections are summarized in Figure 5. All the three nailed connections were sucessfully loaded according to the designated loading protocol, while two out of the three screwed connections experienced failure due to fracture of the screws (see Fig. 3 (b)) before completing the loading protocol.

Improve performance of LVL shear walls was conducted by adding diagonal members according to schematic diagram shown in Fig. 6 [11]. The test was conducted by pulling laterally top member of the LVL walls, while vertical movement of the frame of the wall potentially developed during the test was restrained. It was reported that a significant increase of racking resistance of the shear walls was noticed. This increase was $36 \%, 52 \%$ and $92 \%$ with respect to the walls without diagonal members for the three wall models shown in Fig. 6, respectively [11]. This increase, however, was accompanied by a great decrease of ductility response of the walls; stiffness improve of the frame of the walls has altered the shear wall failure mechanism from ductile to brittle failure mode.

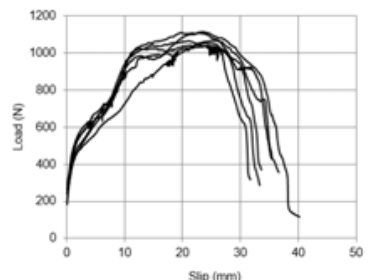

(a)

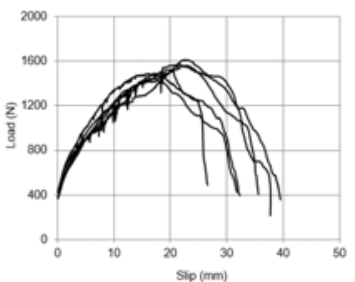

(b)
Fig. 4: Load-slip curve of LVL Sengon sheathing-toframe connections under monotonic load: (a) nailed connection; (b) screwed connection

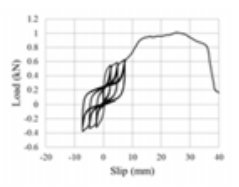

(a) Nailed connection \#1

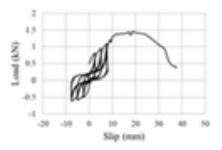

(d) Screwed connection \#1

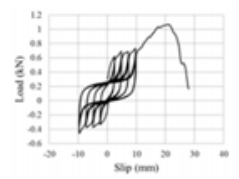

(b) Nailed connection \#2

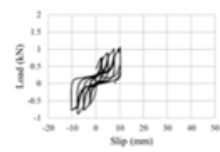

(e) Screwed connection \#2

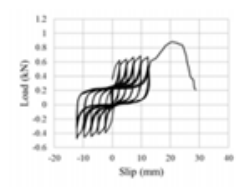

(c) Nailed connection \#3

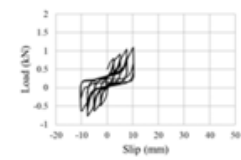

(f) Screwed connection \#3
Fig. 5: Load-slip curve of LVL Sengon sheathing-toframe connections under cycic loads: (a)-(c) Nailed connection; (d)-(f) Screwed connection

Further evaluation of racking resistance of these LVL shear walls under reversed-cyclic tests were performed in this study. The walls were loaded in cyclic at three displacement targets: $0.1 \Delta_{\mathrm{y}}, 0.2 \Delta_{\mathrm{y}}$, and $0.4 \Delta_{\mathrm{y}}$ (the cyclic load are conducted three times at each displacement target) and followed by monotonic load untill failure. Graphs of racking resistance vs. drift ratio obtained from the experiment are indicated in Fig. 7 for the first two wall models given in Fig. 6 where the graph of black line is the racking resistance vs. drift ratio of the shear wall without diagonal members. Energy dissipation or area enclosed by the loop is often denoted by equivalent viscous damping ratio (EVDR) informed that there were an increase of EVDR found in the wall models of Fig. 6 (a) and (b) compare to the wall model without diagonal members. The wall models of Fig. 6 (a) and (b) has almost equal EVDR which is $20 \%$, while the wall model without diagonal members has an EVDR of $13 \%$. 


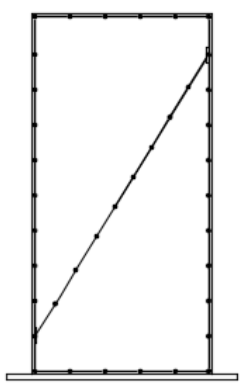

(a)

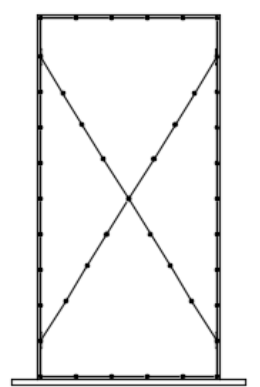

(b)

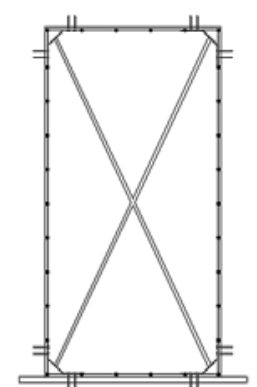

(c)
Fig. 6: Typical improvement of LVL Sengon wooden shear walls: (a) reinforced with one diagonal LVL member; (b) reinforced with two diagonal LVL members: (c) reinforced with two diagonal steel rods [10]

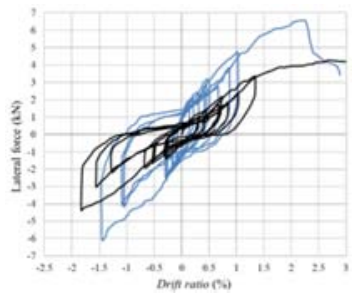

(a)

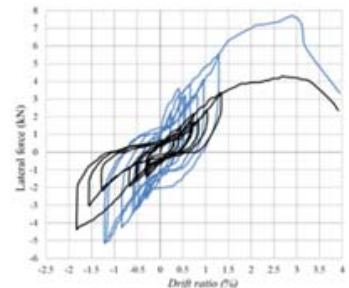

(b)
Fig. 7: Racking resistance vs. drift ratio under cyclic load: (a) shear wall reinforced with one diagonal LVL member (Figure 6.a) and (b) shear wall reinforced with two diagonal LVL members (Figure 6.b) (graph of black line belongs to the shear wall without diagonal members)

An idea of unbonded post-tensioned wooden shear walls appears recently to develope self-centering mechanism of mutli-storey dwellings located in very active seismic regions. Fig. 8 showed an architectural model of multi-storey timber building using low-damage post-tensioned timber technology opened in Christchurch [12]. In this system, the post-tensioned steel rod ensures the closing of the gap between wall elements and foundation causing the structures return to its original position without permanent deformation after the event of an earthquake. The wooden shear walls here are equiped with post-tensioned steel tendons and other energy dissipation devices designed to undergo plastic deformation while the post-tensioned steel tendons remain elastic [13]. A new development by using a conical disc spring proposed by reseachers of Lehigh University as an effort to help possible application of this self-centering system for low and medium-rise buildings accomodating low pre-tension forces [14].

\section{LVL Floor System}

Timber floor systems consist of floor panels and repetitive joists at a prescribed spacing. In most floor designs it is the serviceability requirements that dictate the size and spacing of floor joists $[15,16]$. Box joists and I-joists are the two most common types of built-up joists which are manufactured by combining timber boards and timber solids. A model of floor system $1.2 \mathrm{~m}$ by $2.4 \mathrm{~m}$ made from LVL Sengon was succesfully developed and tested under some configurations of gravity loads as shown in Fig. 9 [17]. It was found that the developed floor model gave bearing load of 18.75 $\mathrm{kN} / \mathrm{m}^{2}$ corresponds to allowable deflection of $L / 300$. This great bearing load capacity, however, has not yet considered potential strength reduction of floor bearing load when creep phenomenom as a result of long-term loading and stiffness reduction due to connection presence in a wider floor area are taken into account.

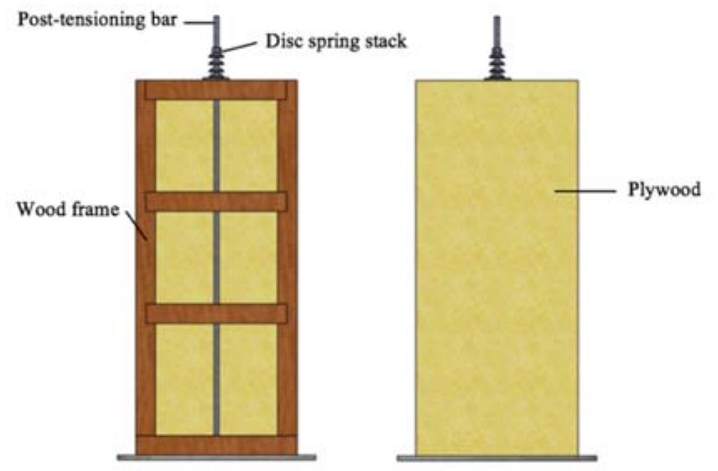

Fig. 8: A proposed un-bonded postensioned wooden shear wall

Creep is defined as an increase of deformation under a constant load and it is very significant in fiber-based materials such as wood [18]. Understanding creep behavior is necessary to anticipate long-term deformation that would limit the performance and service life of our structures [19-24]. Fig. 10 showes a roof structure made of LVL Sengon beams above a pool area where it was reported that after four years of construction large deformation was observed. High humidity due to water evaporation has dramatically increased the moisture content the LVL beams yielding a great increase of beam deflection. An intesive creep investigation of this LVL Sengon is now in progress as shwon in Fig. 11 where both beams and bolted connections were loaded under indoor air conditioned room condition within three months. The outpus of this study is aimed to obtain the creep factor as well as the overall creep behavior of LVL Sengon members, which are substantially characterized by laminas from young trees.

In this creep test the beams and connections were loaded in three different load levels: $30 \%$; $40 \%$; and 50\% of their designed load. For each load level, there were three creep specimens plus one additional connection that is intentionally wraped with plastic to prevent swellingshrinkage activites of the LVL members throughout the test. The LVL Sengon member has dimension of $40 \mathrm{~mm}$ by $80 \mathrm{~mm}$, and length of $2000 \mathrm{~mm}$ for the beam 
specimens and bolt of $6 \mathrm{~mm}$ in diameter for the connection specimens. During creep test, room temperature and relative humidity (RH) were continuously recorded as well as beam deflection and connection slip. Results of this creep study will be elaborated and reported in our future paper.

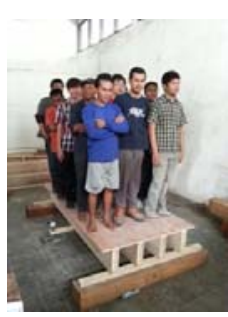

(a)

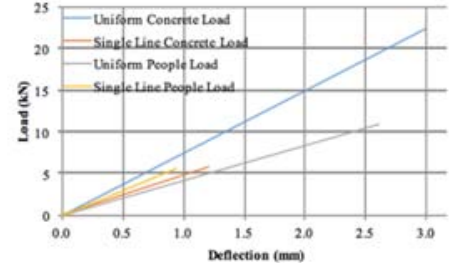

(b)
Fig. 9: Protoype of LVL Sengon floor system: (a) loading configuration; (b) the test results [14]

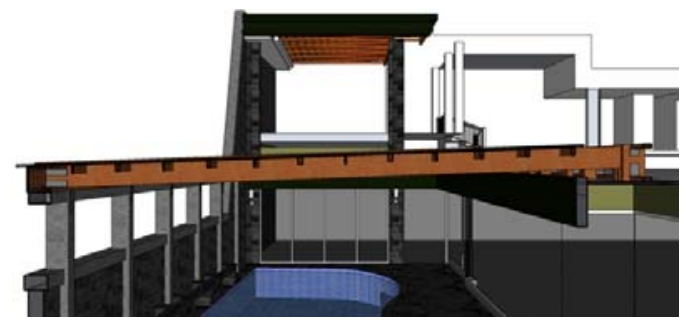

Fig. 10: LVL beams of a roof structure above the pool areas

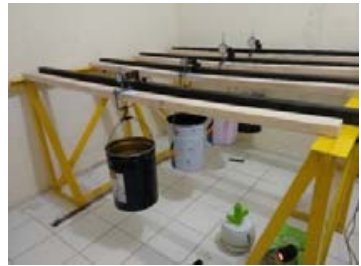

(a)

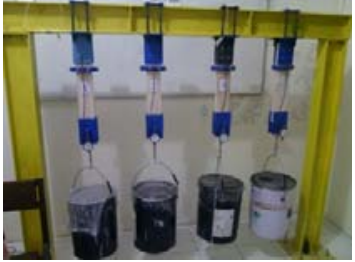

(b)
Fig. 11: Creep test of LVL Sengon: (a) beam specimens; (b) bolted connection specimens

\section{Conclusion Remarks}

As an engineered wood product LVL Sengon has proven its wide application for structural components besides sustainable aspect in term of its availability as Sengon trees are planted in many community forests. Its improved mechanical properties in addition to its short harvesting age makes this LVL Sengon as an innovative and sustainable bulding material in Indonesia that would lessen the national stress due to recent huge housing backlog. Research results summarized in this paper can be futher used for the basis of structural design though some in-depth studies especially on long-term perfomance are still required.

\section{References}

[1] http://makeitwood.org/documents/doc-692timber-as-a-sustainable-material.pdf, date of access: 4 July 2017.

[2] http://www.athenasmi.org/resources/publications /, date of access: 18 August 2017.

[3] https://tekno.tempo.co/read/news/2014/07/01/09 5589444/kerusakan-hutan-indonesia-terusmeningkat, date of access: 4 July 2017

[4] Awaludin, A., Development of Structural Walls made from LVL Sengon (Paraserianthes falcataria): Basic Mechanical Properties, Proc. 1st International Conference on Sustainable Civil Engineering Structures and Construction Materials (SCESCM), Yogyakarta, 2012, pp. 299-302.

[5] Krisnawati, H., Varis, E., Kallio, M., Kanninen, M., Paraserianthes falcataria (L) Nielsen: ecology, silviculture and productivity, CIFOR, Bogor, 2011.

[6] Samirin, W., The evolution of housing finance program in Indonesia, Uganda Housing Finance Conference, 19-20 October, 2016.

[7] Tuomi, R. L., McCutcheon, W. J. Racking strength of light-frame walls, Journal of Structural Division, ASCE, Vol. 104, No. ST7, July, 1978.

[8] Yasumura, M., Racking resistance of panelsheathed shear walls with opening, World Conference on Timber Engineering, Vol. 2, pp. 1169-1176, 2010.

[9] McCutcheon WJ., Racking deformation in wood shear walls, Journal of Structural Engineering, ASCE, Vol. 111(2), pp. 257-269. 1985.

[10] Hadi, M., Murakami, S., Kitamori, A., Chang, WS., Komatsu, K., Performance of shear wall composed wih LVL and cement fiber board sheathing, Journal of Asian Architecture and Building Engineering, vol. 9(2), pp. 463-469.

[11] Awaludin, A., Pribadi, A., Satyarno, I., Racking resistance of Paraserianthes falcataria wooden panel under monotonic load, Proc. of Civil Engineering Conference in Asia-Pacific Region (CECAR), Jakarta, paper \# 79, 2013.

[12] https://nz.pfolsen.com/market-info-news/woodmatters/2014/april/first-post-tensioned-timberbuilding-opens-in-christchurch/ date of access: 18 August 2017.

[13] Moroder D., Pampanin S., Palermo A., Smith T., Sarti F., Buchanan A., 2017, Diaphragm connection in structures with rocking timber walls, Journal of Structural Engineering International, Vol. 27(2), pp. 165-174. 
[14]Al-Subaihawi., S., Pessiki, S., Static and dynamic analysis of manually post-tensioned timber rocking frame with conical disc spring, ATLSS Report 17-03, Lehigh University, Bethlehem June, 2017.

[15] Boise Cascade, Simple Framing System: A Technical Guide Floor \& Roof Framing Constructions BS5268 PART 2:2002 Version, 2013

[16]APA, Design and Fabrication of Glued Plywood-Lumber Beams in Plywood Design Specification. APA, USA, 1998.

[17] Awaludin, A., Firmanti, A., Muslikh, Theodarmo, H., Astuti, D., Wood Frame Floor of LVL Paraserianthes falcataria, Proc. 3rd International Conference on Sustainable Civil Engineering Structures and Construction Materials (SCESCM), Yogyakarta, Vol.17, pp. 113-120, 2017.

[18] Awaludin, A., Ngudiyono, Basuki, A., Creep properties of Walikukun (Schouthenia ovata) timber beams, Journal of Civil Engineering Dimension, Vol. 18(2), pp. 78-84, 2016.

[19]Amino, Y., Bamboo-Precocious Wood Composite Beams: Bending Capacity for LongTerm Loading, Journal Bamboo and Rattan, 4(1), pp. 55-70, 2005.
[20]Fidley, K. J., Tang, R. C., and Soltis, L. A., Creep Behavior Model for Structural Lumber, Journal of Structural Engineering, ASCE, 118(8), pp. 2261 - 2277, 1992.

[21] Ma, Y., Li, X., Deng, B., and Luo, Y., Basic Study on Creep Properties of Eucalyptus Wood, Advanced Material Research, 911, pp. 232-237, 2014.

[22] N. Ali, N. A. Zainal, M. K. Burhanudin, A. A. Abdul Samad, and S. Shahidan, "Physical and Mechanical Properties of Compressed Earth Brick ( CEB ) Containing Sugarcane Bagasse Ash," MATEC Web Conf., vol. 47, pp. 1-7, 2016.

[23] S. Azhar, A. Tajudin, M. Azim, M. Azmi, and S. Shahidan, "Relationship of Physical Parameters in $\mathrm{Pb}$-Contaminated by Stabilization / Solidification Method," MATEC Web Conf., vol. 47, pp. 3-8, 2016.

[24] S. Shahidan, N. M. Bunnori, N. M. Nor, and S. R. Basri, "Health Index Evaluation on Acoustic Emission Signal for Concrete Structure by Intensity Analysis Method," Adv. Mater. Res., vol. 403-408, pp. 3729-3733, 2011. 